\title{
MUSLIM WORLD JOURNAL OF HUMAN RIGHTS
}

\section{EDITOR-IN-CHIEF}

Turan Kayaoglu, University of Washington Tacoma

\section{EDITORS}

Mashood Baderin, School of Oriental and African Studies

Mahmood Monshipouri, San Francisco State University

Lynn Welchman, School of Oriental and African Studies

BOOK REVIEW EDITOR

Chrystie Flournoy Swiney, Georgetown University

\section{DEVELOPMENT EDITOR}

Elizabeth Marsch, American University

\section{ADVISORY BOARD}

Abdullahi An-Na'Im, Emory Law School

Cherif Bassiouni, DePaul Law School

John L. Esposito, Georgetown University

Abdulaziz A. Sachedina, University of Virginia

\section{ASSOCIATE EDITORS}

Anthony Chase, Occidental College

Jack Donnelly, University of Denver

Nader Hashemi, University of Denver

Ziba Mir-Hosseini, University of London

Tamara Sonn, The College of William and Mary

Anicée Van Engeland-Nourai, University of Exeter

\section{DE GRUYTER}


Muslim World Journal of Human Rights offers a medium for scholarly debate on various aspects of the question of human rights as it relates to the Muslim World. Edited by an international board of leading Islamic studies, Middle Eastern studies and human right scholars from around the world, MWJHR promises to serve as a forum in which barriers are bridged (or at least, addressed), and human rights are finally discussed with an eye on the Muslim world, in an open and creative manner. The choice to name the journal, "Muslim World Journal of Human Rights" reflects a desire to examine human rights issues related not only to Islam and Islamic law, but equally those human rights issues found in Muslim societies that stem from various other sources such as socio-economic and political factors, as well the interaction and intersections of the two areas.

ABSTRACTED/INDEXED IN Baidu Scholar · Cabell's Whitelist · CNKI Scholar (China National Knowledge Infrastructure) · CNPIEC: cnpLINKer · Dimensions · EBSCO (relevant databases) · EBSCO Discovery Service · Genamics JournalSeek · Google Scholar · IBR (International Bibliography of Reviews of Scholarly Literature in the Humanities and Social Sciences) · IBZ (International Bibliography of Periodical Literature in the Humanities and Social Sciences) - Index Islamicus . International Bibliography of the Social Sciences (ProQuest) $\cdot$ J-Gate $\cdot$ JournalGuide $\cdot$ JournalTOCs . KESLI-NDSL (Korean National Discovery for Science Leaders) · Microsoft Academic · MyScienceWork · Naver Academic · Naviga (Softweco) · PhilPapers · Primo Central (ExLibris) · ProQuest (relevant databases) · Publons · QOAM (Quality Open Access Market) · ReadCube · SCImago (SJR) - SCOPUS · Semantic Scholar · Sherpa/RoMEO - Summon (ProQuest) - TDNet · Ulrich's Periodicals Directory/ulrichsweb · WanFang Data · WorldCat (OCLC)

ISSN 2194-6558 · e-ISSN 1554-4419

All information regarding notes for contributors, subscriptions, Open Access, back volumes and orders is available online at http://www.degruyter.com/mwjhr.

RESPONSIBLE EDITOR Turan Kayaoglu, University of Washington Tacoma, Email: turan@uw.edu JOURNAL MANAGER Nathan Gamache, De Gruyter, Genthiner Straße 13, 10785 Berlin, Germany, Tel.: +49 3026005 296, E-mail: Nathan.Gamache@ degruyter.com

RESPONSIBLE FOR ADVERTISEMENTS Markus Kügel, De Gruyter, Rosenheimer Str. 143, 81671 München, Germany, Tel.: +49 8976 902-424, E-mail: anzeigen@degruyter.com

(C) 2021 Walter de Gruyter GmbH, Berlin/Boston

TYPESETTING TNQ Technologies, Chennai, India

PRINTING Franz X. Stückle Druck und Verlag e.K., Ettenheim

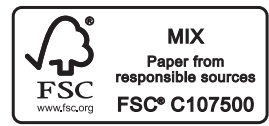




\section{Contents}

\section{Research Articles}

Christopher Mark Joll

Contextualizing Discrimination of Religious and Linguistic Minorities in South Thailand -1

Devran Gülel

A Critical Assessment of Turkey's Positive Obligations in Combatting Violence against Women: Looking behind the Judgments — 27

Mehmood Hussain and Sumara Mehmood

Genocide in Kashmir and the United Nations Failure to Invoke Responsibility to Protect (R2P): Causes and Consequences - 55

Andi Muhammad Irawan and Zifirdaus Adnan

The Ahmadiyya, Blasphemy and Religious Freedom: The Institutional Discourse Analysis of Religious Discrimination in Indonesia - 79

Hassan M. Ahmad

Re-Assessing the Evidentiary Threshold for Zinā' in Islamic Criminal Law: A De Facto Exemption Proposal -103

Cekli Setya Pratiwi and Sidik Sunaryo

Blasphemy Law as a Structural Violence: A Challenge for Maintaining Sustainable Peace 133

Antonio-Martín Porras-Gómez

Limitation Clauses and Constitutional Transformation: The Case of the New Arab Constitutions -167 